\title{
NOVICE AND EXPERIENCED TEACHERS' VIEWS ON PROFESSIONALISM
}

\author{
Anne Okas ${ }^{1}$, Marieke van der Schaaf ${ }^{2}$, and Edgar Krull ${ }^{1}$ \\ ${ }^{1}$ University of Tartu and ${ }^{2}$ Utrecht University
}

\begin{abstract}
This article discusses teachers' practical knowledge and beliefs of their profession based on reflective writings of twenty Estonian teachers.Ten novice and ten experienced teachers participated in the study. They put together their professional portfolios, which among other documents included reflective writings regarding professionalism. The teachers' writings enabled us to qualitatively analyse how they described and interpreted their teaching activities and what being a professional teacher means to them. The results showed that when speaking about the image of a professional teacher, novice teachers stressed technological teaching aspects, for instance - skills in using IT equipment. The essays by the experienced teachers included more keywords related to the development of students and stressed the teacher's role as an educator. Both novice and experienced teachers valued the pedagogical education of teachers.
\end{abstract}

Keywords: novice teachers, experienced teachers, professionalism, reflection, teachers' practical knowledge

DOI: $10.3176 /$ tr.2014.4.02

\section{Introduction}

\subsection{Teacher professionalism}

There is an internationally recognized need to increase the prestige of teaching profession. A profession is an occupation with certain prestige thanks to its intellectual or artistic nature, which stems from the social positions of the people with that specific occupation (Krull 2002). In many countries the teaching profession struggles with image improvement and accountability requirements. For example, the central mission of teacher education in Finland has been research-oriented approach to teaching which will enhance teachers' professionalism (Westbury, Hansen, Kansanen, and Björkvist 2005). In Finland policy-makers are influenced by notions of 'teacher empowerment' while in 
England they try to raise standards and 'commercialized professionalism' (Webb, Vulliamy, Hämäläinen, Sarja, Kimonen, and Nevalainen 2004). The Union of Education Norway is working to enhance the status and legitimacy of the teaching profession (Mausethagen and Granlund 2012). Consequently worldwide efforts are undertaken to ensure teacher quality in schools. One way to improve the quality of the teaching profession is to introduce certification of teachers based on national professional teaching standards. Another way is to use performance management systems in schools that monitor teachers' quality. The profits of these efforts show mixed results, e.g. Goldhaber and Brewer (2000) and underline the need to gain further insight in the meaning of teacher professionalism. Especially a teacher's own perception of the teaching quality is the key, since this steers how he or she might act in daily practice (Eraut 2008). Consequently this study examines how Estonian teachers perceive the teaching profession.

According to Hoyle and John (1995) being a professional has three main points of emphasis: knowledge, autonomy and responsibility.

First, we can talk about a profession when its representatives possess a complex of knowledge, beliefs and skills that is recognised and accepted by representatives of other fields. D. C. Corrigan and M. Haberman (1990) characterise a profession using four significant features: basic knowledge; assurance of qualifications; resources; and practice conditions. Every recognised field is characterised by knowledge, beliefs and skills that are commonly possessed by all of the practitioners in the field and not usually possessed by people not related to the field. These rely on theory, research, professional values and work ethics of the specific field.

Secondly, professionals are characterized by autonomy, i.e. the right of selfgovernment and independence (The Oxford Reference Dictionary 1992:55). The choice of methods to reach predetermined goals and standards is the main aspect of teachers' autonomy (Šteh and Požarnik 2005).

Autonomy of action and authority are important in applying the existing knowledge, attitudes and skills in a specific work situation. In the teaching context this means that the professional skills and knowledge of a teacher can only be fully expressed if the teacher has sufficient decision-making rights, authority among students, colleagues, parents and the general public and the material conditions and equipment needed to conduct teaching and educating activities (Krull 2002).

Third, in the concept of professionalism, teacher autonomy holds a central position and it is closely linked to ethical responsibility - the ability to make responsible choices in promoting active learning, meaningful knowledge and also autonomy in their students (Niemi and Kohonen 1995, Šteh and Požarnik 2005). The notion of teacher professionalism is closely related to professional development (Evans 2008, Hargreaves 2001). 


\section{Professional development}

The characteristic features of professionalism are displayed and reflected as specific features of the representatives of an area that have developed as a result of natural prerequisites, professional preparation and practice. Depending on the area, development from novice to professional takes a shorter or longer period of time. Teachers' work requires an extraordinarily good knowledge of the human psyche and a sense of social context, which is why professionalism in this field is achieved through years of professional work (Krull 2002). According to Fuller (1969), the professional development of a teacher is reflected in the formation of their problemawareness (see Table 1). Using data obtained directly from 50 student teachers and indirectly from other databases and reports of similar surveys, Fuller (1969) inferred a three-stage model of teacher development that focused teachers' concerns. The main problem for novice teachers is how to control a class full of children. When a group is small, their main concern is mostly their relationship with the students. As a teacher becomes more competent and self-confidence grows, the emphasis shifts to more serious concerns related to teaching and learning. Novice teachers can only discuss middle phase concerns (competence) theoretically; experienced teachers handle this with ease. Put simply, teachers who have trouble maintaining order in the classroom are probably not capable of handling later phase concerns (Eraut 2008). In the first pre-teaching stage, candidates tend to identify realistically with pupils but unrealistically with teachers. Their concerns as teachers consist of only vague apprehensions. The second stage is characterised by concerns for survival: class control; mastery of content; the teacher's own adequacy in fulfilling his/her role. In the third stage, concerns turn to teaching performance and the limitations and frustrations of teaching situations (Kagan 1992:160).

Several years later, Fuller's model was modified to accommodate a fourth stage (Fuller and Bown 1975). In the fourth and final stage, the teacher's concerns turn to pupils: their social, academic and emotional needs, and the teacher's ability to relate to pupils as individuals (Kagan 1992). Shortly, teachers' concerns have been conceptualized as classifiable into two groups: concerns about benefit to self and concerns about benefit to pupils (Fuller 1969).

Table 1. Fuller's model of teacher development

\begin{tabular}{|c|c|c|c|}
\hline I & Early phase & 0 & Concerns about self (non-teaching concerns) \\
\hline II & Middle phase (competence) & 2 & $\begin{array}{l}\text { Concerns about professional expectations and } \\
\text { acceptance } \\
\text { Concerns about one's own adequacy: subject matter } \\
\text { and class control } \\
\text { Concerns about relationship with students }\end{array}$ \\
\hline III & Late phase (professionalism) & $\begin{array}{l}4 \\
5 \\
6\end{array}$ & $\begin{array}{l}\text { Concerns about students learning what is taught } \\
\text { Concerns about students learning what they need } \\
\text { Concerns about one's own (teacher's) contributions } \\
\text { to student change }\end{array}$ \\
\hline
\end{tabular}

Source: adapted from Fuller 1970. 
Another viewpoint is taken by Berliner (1994) who described a model of teacher development. According to Berliner, five consecutive stages of development are involved before a teacher reaches expert level: the novice stage; the advanced beginner stage; the competent stage; the proficient stage; and the expert stage. The formation of professional skills begins at the lowest level by following rules without any context and reaches the highest level only among a small number of teachers. In traditional teaching situations the expert teacher relies on automatism and intuition, thanks to which they can concentrate on solving untraditional pedagogical issues more than less experienced colleagues. At all five levels of development the differences in professional skills can be divided into four: how the teacher observes (or is able to observe) what is going on in the classroom; how tense the teacher is when teaching; to what extent the teacher relies on personal experience in foreseeing events; and to what extent the teacher's attention is focussed on supporting the work of students as opposed to worrying about their own work (Kagan 1992).

To better understand the professionalism of a teacher two important aspects must be borne in mind. Firstly, a teacher's development in becoming an expert in their field is a long-term process characterised by qualitative changes in teaching skills. Secondly, understandings of teacher's professionalism - professional competence - can vary (Krull, Leijen, Lepik, Mikk et al. 2013). In addition, teacher's professional self-assessment is linked to several other aspects of professional effectiveness, such as job satisfaction, professional commitment and personal efficiency (Day 2002). This paper elaborates on the aspect of practical knowledge - a teacher's knowledge and beliefs - related to professionalism. We hope you agree that good teaching is not an accident. This is the result of teacher education studies, hard work, e.g. practice in the classroom, and reflection. Mizell (2010) said that a teacher can never know enough about how a student learns, and how the teacher's instruction can increase the student learning. Professional development is the only means for teachers to gain such practical knowledge.

\section{Teachers' knowledge and beliefs}

To fulfil the main tasks of teaching, a teacher must have a combination of theoretical and practical knowledge which together is viewed as a teacher's knowledge and beliefs. Teachers' knowledge and beliefs about teaching, students and the subject matter are central because they function as interpretative lenses through which teachers make sense of the situation (Van der Schaaf 2005). Teacher knowledge and beliefs are developed by experiences derived from teacher actions.

Teachers' knowledge and beliefs have been an object of study for the past few decades (Calderhead 1996, Fenstermacher 1994, Meijer, Verloop and Beijaard 1999, Meijer, Verloop and Beijaard, 2002, Okas, Van der Schaaf and Krull 2013a, Okas, Van der Schaaf and Krull 2013b). Many researchers define practical knowledge as a combination of professional knowledge, skills and attitudes on which 
the teachers base their pedagogical decisions in everyday work (Meijer 1999, Meijer, Verloop and Beijaard 2002, Schepens, Aelterman, Van Keer 2007, (Krull and Raudsepp 2010). On the one hand these decisions are based on generalisations, attitudes and beliefs formed as part of previous work experience and gained through studying theory; on the other, the current situation in the classroom and interaction with the students also affects the teacher's decisions. Knowledge and beliefs form a framework in which the teacher deals with the work practice and these relate to long-term memory and function as statements of considering of an action (Meijer 1999, Schepens et al. 2007, Krull and Raudsepp 2010).

Knowledge and beliefs are personal and unique, can be tacit or conscious, context-specific or general-theoretical (Beijaard and Verloop 1996, Van der Schaaf 2005). Due to the unique character of teachers' knowledge and beliefs, teachers differ in what they know and what they think that works in practice. We assume that it is especially the case for novice and experienced teachers. Professionalism in teaching cannot be achieved without teachers' knowledge and beliefs.

\section{Teachers' reflective writings}

Reflection is regarded as a condition for teachers having the capacity to continue to steer their own professional development (Korthagen 2001). Reflection is a tool for improving teaching. In general, reflection is seen as a way of systematically thinking about experiences, frequently coupled to action in education practice, and arising from a problem experienced (Hatton and Smith 1995).

Often teachers do not have time to reflect on their activities: the decisions they had to make during teacher training were entirely different from the ones they have to (often intuitively and on the spot) make in the classroom. There is a great deal of stress because of that. M. Eraut calls interaction in the classroom ' $h o t$ action', while, for example, the action in the lawyers consulting room is usually rather cooler (Eraut 2008). A professional teacher, however, has to be able to reflect on their activities if they are to make their teaching more effective. Professionals are expected to understand how they perform and to use this information to plan their professional development, building on strengths and addressing weaknesses (Hays and Gay 2011).

Teachers' reflective writings are valid instruments to explicate teachers' knowledge and beliefs. This is evidenced by the fact that many teacher training programmes let aspiring teachers write reflective essays to develop their skills of reflection and support them on their path to becoming teachers (Broekman and Scott 1999, Hoover 1994, Poldner, Van der Schaaf, Simons, Tartwijk and Wijngaards 2014).

This article discusses teachers' knowledge and beliefs of their profession based on the essays and reflective writings of 20 Estonian teachers. The research question: What are novice and experienced teachers' views on professionalism in their field and how do they differ? 


\section{Method}

\subsection{Design}

The qualitative study has been carried out in seven Estonian primary schools. The study is part of a larger research project in which novice and experienced teachers had to put together professional portfolios (see: Okas et al. 2013a, 2013b). Van der Schaaf and Stokking's (2008) model of teacher portfolio was used as a format because in this model we can see most clearly the teachers knowledge, beliefs and behaviour. The portfolio contained the following components: a selfdescription; a selection of tasks that could be assigned to students; two recordings of interviews (one pre-lesson and one post-lesson, conducted using the stimulated recall method); a videorecording of the lesson; the teacher's reflective writings on their strengths and weaknesses; the teacher's essays about what makes a teacher professional; and students' assessments of the actions or behaviour of their teacher during the lesson. In this study a greater role is played by essays and reflective writings by teachers. Our interest was to clarify the differences in novice and experienced teachers' views on teachers' professionalism.

\subsection{Sample}

Twenty primary school teachers (18 females and two males, 10 of them novices and 10 experienced) voluntarily took part in the study. The teachers' work experience varied: those with experience had worked at the schools for at least 10 years, while the most experienced had worked there for 44 years. The novice teachers were at early points in their careers (with up to three years' experience). The teachers who participated in the study taught various subjects at grades 6-9 of primary school: Estonian as a first language; English as a foreign language; maths; chemistry; biology; geography; and history.

\subsection{Data collection}

This article reflects the results of the study, which were obtained by analysing two components of the portfolio:

1) the teacher' essays about what makes a teacher professional; and

2 ) the teachers' reflective writings on their strengths and weaknesses.

The teachers did not get any specific instructions for the reflective writings and essays, just the topics "What makes a teacher professional?" and "My strengths and weaknesses as a teacher". Teachers wrote reflective writings and essays at home individually, during one week.

\subsection{Instrumentation}

The teachers' reflections in their essays "What makes a teacher professional?" were categorised according to the categories of teachers' knowledge and beliefs (Meijer 1999, Van Driel, Verloop and Vos 1998). The grouping was based on these categories because they enable teachers' reflections to be effectively systematised (Meijer et al. 1999). The codebook included seven different 
categories (knowledge of students; knowledge of students' learning and understanding; knowledge of one's subject; knowledge of curricula; knowledge of aims; knowledge of instruction techniques and methods in teaching technology; knowledge of teacher), first six of them from Dutch studies. The reason why we included the 7th category - knowledge of teacher - was because there were a number of descriptions about their personal characteristics.

In our case there were two experts who each classify 387 keywords into seven categories. Cohen's kappa coefficient and percentage agreement were computed to estimate the inter-rater agreement. In this case, the calculated value of Cohen's kappa $(0,67)$ confirms that the agreement in categorization was good $(79 \%$ agreement).

The system of categories for analysing the reflective writings "My strengths and weaknesses as a teacher" i.e. the codebook included four categories: teaching and teaching technology; communication; knowledge of the subject; personal characteristics. Two experts classified 357 keywords into four categories. The quality of the experts agreement was assessed by computing Cohen's kappa for measuring the agreement between two experts who categorized the keywords by the teachers into these categories. The quality of the agreement in this case was very good $(90 \%$ agreement; Cohen's kappa $=0,86)$.

\subsection{Data analysis}

The qualitative content analysis of essays was aimed at describing teachers' understandings of teachers' professionalism, categorizing the stated keywords, and for revealing differences between novice and experienced teachers' practical knowledge and beliefs. In total, 387 keywords were counted from the essays. For the content analysis, overlaps and expressions with similar meanings were grouped under 36 keywords. We call these keywords subcategories. The subcategories were divided into seven wider areas that covered all six categories of the teachers' practical knowledge and beliefs (Meijer et al. 1999, Van Driel et al. 1998) and an additional seventh category for the personal characteristics of a teacher. Also, the content analysis of reflective writings was aimed categorizing the teachers presented weaknesses and strengths. 357 keywords were counted from the reflective writings. These keywords were divided into four categories according to the codebook.

\section{Results}

The results are presented in two parts in this article. Firstly, we analyse the teachers' essays in which they presented their opinions by answering the question "What makes a teacher professional?" The second part of results deals with the teachers' opinions of their professionalism, highlighting their own strengths and weaknesses. 


\subsection{Novice and experienced teachers views on professionalism}

The analysis revealed that all six categories of knowledge and beliefs (Meijer 1999, Van Driel et al. 1998) were represented in the teachers' reflections. Additionally, we added a seventh category which notes a teacher's knowledge and beliefs regarding their personal traits/characteristics. Next, we present, based on Van Driel et al. (1998) and Meijer (1999) and supplementing them, seven categories and 36 subcategories with examples (see Table 2).

Abbreviations' meaning in examples: $\mathrm{F}$ - female; $\mathrm{M}$ - male (gender); $\mathrm{N}$ novice; $\mathrm{E}$ - experienced (working experience).

Table 2. Categories and subcategories with examples of teachers' knowledge and beliefs

\begin{tabular}{|c|c|c|}
\hline $\begin{array}{l}\text { Categories of practical } \\
\text { knowledge and beliefs }\end{array}$ & Subcategories & Examples \\
\hline \multirow[t]{5}{*}{ Knowledge of students } & Developing the student & $\begin{array}{l}\text { A professional teacher is a person whose } \\
\text { actions are based on the interests of the } \\
\text { learner's development (FE). }\end{array}$ \\
\hline & $\begin{array}{l}\text { Considering the } \\
\text { individual differences of } \\
\text { the students }\end{array}$ & $\begin{array}{l}\text { Every student is a unique individual who } \\
\text { requires a specific approach, be it more strict } \\
\text { or lenient (FE). } \\
\text { A professional teacher considers the } \\
\text { students' capability to learn. I would like to } \\
\text { say here that the work capability of current } \\
\text { students is very low (ME). }\end{array}$ \\
\hline & $\begin{array}{l}\text { Considering the specific } \\
\text { nature of the students } \\
\text { depending on their age }\end{array}$ & $\begin{array}{l}\text { Attention should be paid to every student } \\
\text { and his or her characteristics depending on } \\
\text { their age should be considered (FN). }\end{array}$ \\
\hline & $\begin{array}{l}\text { Supporting weaker } \\
\text { students/making the } \\
\text { learning process attain- } \\
\text { able for them }\end{array}$ & $\begin{array}{l}\text { A professional teacher notices and supports } \\
\text { the weaker (FE). } \\
\text {...always tries to help the weaker keep track } \\
\text { and does not have a bad attitude towards } \\
\text { them (FN). }\end{array}$ \\
\hline & $\begin{array}{l}\text { Psychological } \\
\text { knowledge/especially } \\
\text { mastering communica- } \\
\text { tions psychology }\end{array}$ & $\begin{array}{l}\text { A professional teacher is a good psycho- } \\
\text { logist and first and foremost a good } \\
\text { communicator (FN). } \\
\text { Communication and relations with students } \\
\text { are key (FE). }\end{array}$ \\
\hline \multirow[t]{2}{*}{$\begin{array}{l}\text { Knowledge of students' } \\
\text { learning and understand- } \\
\text { ing }\end{array}$} & $\begin{array}{l}\text { Creating an environment } \\
\text { to support learning }\end{array}$ & $\begin{array}{l}\text { The teacher's skill in creating an environ- } \\
\text { ment in the classroom that promotes learn- } \\
\text { ing is important (FE). The main goal is to } \\
\text { make the information that is learned under- } \\
\text { standable (FE). }\end{array}$ \\
\hline & $\begin{array}{l}\text { Guarantor of a safe learn- } \\
\text { ing environment }\end{array}$ & $\begin{array}{l}\text { Children can learn only when they feel safe } \\
\text { in the classroom (FN). }\end{array}$ \\
\hline
\end{tabular}




\begin{tabular}{|c|c|c|}
\hline Categories of practical & Subcategories & Examples \\
\hline & $\begin{array}{l}\text { Valuing the creating of } \\
\text { interest in learning } \\
\text { Encouraging }\end{array}$ & $\begin{array}{l}\text { A professional teacher can make even the } \\
\text { most boring material interesting (FE). They } \\
\text { teach in a way that students become } \\
\text { interested and understand the processes in } \\
\text { depth, not by heart (FE). A professional } \\
\text { teacher is a specialist in their field who can } \\
\text { make students think and become interested } \\
\text { in a subject (FN). } \\
\text { Teachers like this can create a wow factor } \\
\text { and make students enthusiastic (FN). }\end{array}$ \\
\hline & Willingness to cooperate & $\begin{array}{l}\text { Professional teaching and learning means } \\
\text { cooperation between the students and the } \\
\text { teacher }(\mathrm{FN}) \text {. }\end{array}$ \\
\hline & $\begin{array}{l}\text { Linking learned informa- } \\
\text { tion to everyday life }\end{array}$ & $\begin{array}{l}\text { It is easier to learn if the theoretical material } \\
\text { can instantly be linked with practice (ME). }\end{array}$ \\
\hline \multirow[t]{5}{*}{ Knowledge of subject } & $\begin{array}{l}\text { Education Professional } \\
\text { preparation }\end{array}$ & $\begin{array}{l}\text { A professional teacher is educated and has } \\
\text { very good professional preparation (FN). }\end{array}$ \\
\hline & Knowledge of the subject & $\begin{array}{l}\text { A professional teacher has an excellent } \\
\text { knowledge of their subject (FN). Pro- } \\
\text { fessionals know their area and subject well } \\
\text { (FE). }\end{array}$ \\
\hline & Broad range of interests & $\begin{array}{l}\text { A professional teacher has a broad range of } \\
\text { interests (FE), ...has diverse interests and } \\
\text { knowledge (FE). }\end{array}$ \\
\hline & $\begin{array}{l}\text { Participation in training } \\
\text { programmes }\end{array}$ & $\begin{array}{l}\text { A professional teacher is constantly better- } \\
\text { ing themselves (FE). }\end{array}$ \\
\hline & $\begin{array}{l}\text { Constant self- } \\
\text { development }\end{array}$ & $\begin{array}{l}\text { Professional teachers are constantly } \\
\text { developing (FE). }\end{array}$ \\
\hline Knowledge of curricula & Capacity of curriculum & $\begin{array}{l}\text { It should be stated in the law that in their } \\
\text { first year of work novice teachers have } \\
\text { fewer classes because the curriculum is } \\
\text { dense and getting to know the materials and } \\
\text { preparing classes takes a lot of time (FE). }\end{array}$ \\
\hline \multirow[t]{4}{*}{ Knowledge of aims } & $\begin{array}{l}\text { Shaper of students' view } \\
\text { of the world }\end{array}$ & $\begin{array}{l}\text { Professional teachers also shape the right } \\
\text { opinions (FE). }\end{array}$ \\
\hline & $\begin{array}{l}\text { Shaper of students' } \\
\text { attitudes }\end{array}$ & $\begin{array}{l}\text { Professional teachers shape students' values } \\
\text { and attitudes, for instance, sustainable } \\
\text { attitudes towards the environment and } \\
\text { nature (FE). }\end{array}$ \\
\hline & $\begin{array}{l}\text { Shaper of students' self- } \\
\text { discipline }\end{array}$ & $\begin{array}{l}\text { The teacher's task is to mould, with the help } \\
\text { of the subject, people who can cope on their } \\
\text { own in life (ME). Raising self-discipline is } \\
\text { part of teaching (FE). }\end{array}$ \\
\hline & $\begin{array}{l}\text { Instilling order in } \\
\text { students }\end{array}$ & $\begin{array}{l}\text { Instilling order and cleanliness in students is } \\
\text { very important (FE). }\end{array}$ \\
\hline
\end{tabular}




\begin{tabular}{|c|c|c|}
\hline $\begin{array}{l}\text { Categories of practical } \\
\text { knowledge and beliefs }\end{array}$ & Subcategories & Examples \\
\hline \multirow[t]{4}{*}{$\begin{array}{l}\text { Knowledge of instruction } \\
\text { techniques and methods } \\
\text { in teaching technology }\end{array}$} & $\begin{array}{l}\text { Use of different work } \\
\text { approaches } \\
\text { Use of different teaching } \\
\text { methods }\end{array}$ & $\begin{array}{l}\text { Every class should be interesting for the } \\
\text { students and include group work, } \\
\text { independent work, creative tasks and } \\
\text { discussion (FE). }\end{array}$ \\
\hline & $\begin{array}{l}\text { Use of modern } \\
\text { technology in teaching } \\
\text { E-learning }\end{array}$ & $\begin{array}{l}\text { A professional teacher uses e-learning (FN). } \\
\text { During my years of teaching I've tried } \\
\text { several methods and my opinion is that to } \\
\text { get good results you should not put on a } \\
\text { show like 'Song and Dance festival' in the } \\
\text { classroom - a classic lesson with minor } \\
\text { variation works the best. The efficiency } \\
\text { factor of e-learning is rather small (ME). }\end{array}$ \\
\hline & $\begin{array}{l}\text { Uploading study } \\
\text { materials online }\end{array}$ & $\begin{array}{l}\text { Smart teachers upload study materials and } \\
\text { interact on Facebook, because that's where } \\
\text { the students are (FN). }\end{array}$ \\
\hline & $\begin{array}{l}\text { Using online materials } \\
\text { Guiding students in using } \\
\text { the Internet }\end{array}$ & $\begin{array}{l}\text { The teacher must guide the student in using } \\
\text { additional sources and help them draw } \\
\text { logical conclusions (FN). }\end{array}$ \\
\hline \multirow[t]{12}{*}{ Knowledge of teacher } & Open communication & A professional teacher is open (FE) \\
\hline & Positivity & ... has a positive attitude (FE). \\
\hline & Justice & $\begin{array}{l}\text { Professional teachers are fair and honest } \\
\text { regarding students (FN). }\end{array}$ \\
\hline & Demanding & $\begin{array}{l}\text { A professional teacher is demanding but } \\
\text { does not have a bad attitude towards } \\
\text { students (FE). }\end{array}$ \\
\hline & Empathic & $\begin{array}{l}\text { A professional teacher understands students' } \\
\text { problems and is empathic }(\mathrm{FN}) \text {. }\end{array}$ \\
\hline & Understanding & $\begin{array}{l}\text { Professional teachers are understanding, } \\
\text { helpful and accommodating (FN). You have } \\
\text { to be on the same level as the students, } \\
\text { otherwise you'll achieve no results (ME). }\end{array}$ \\
\hline & Calm & The teacher has to be calm and patient (FE). \\
\hline & Balanced & Teachers have to be balanced (FE). \\
\hline & Dedication & $\begin{array}{l}\text { I think the word 'professional' is not } \\
\text { necessary here - a teacher is someone who } \\
\text { puts their heart into their work (FE).... is } \\
\text { caring and dedicated (FE). }\end{array}$ \\
\hline & Self-analysis skills & $\begin{array}{l}\text { As a professional, a teacher has to be able to } \\
\text { analyse what they do so as to perceive the } \\
\text { teaching and education process in all its } \\
\text { complexity (FE). } \\
\text { Has to analyse themselves and their } \\
\text { activities - both successes and failures (FN). }\end{array}$ \\
\hline & Expressing skills & $\begin{array}{l}\text { Teachers must know how to express them- } \\
\text { selves properly (FE). }\end{array}$ \\
\hline & Interesting personality & $\begin{array}{l}\text { A professional teacher is a person who is an } \\
\text { individual (FN). }\end{array}$ \\
\hline
\end{tabular}


The analysis revealed that all categories of teachers' knowledge and beliefs were represented in teachers' writings. The largest number of reflections (98) was about teachers personal characteristics (see Figure 1). Novice teachers made more statements than experienced teachers regarding this category. Also, a large number of reflections was about instruction techniques and methods in teaching technology (76), about students (70) and students learning and understanding of the material learned (69).

In summary, in novice and experienced teachers essays about teachers' professionalism the central issues were teachers' personal characteristics and instructional techniques. Differences revealed in comments about using the technology equipment. All novice teachers $(\mathrm{n}=10)$ submitted ideas with different emphases of IT tools in the classroom. At the same time, only four experienced teachers from ten pointed out the possibilities of IT implementation as a component of teacher professionalism, two of them with negative attitude.

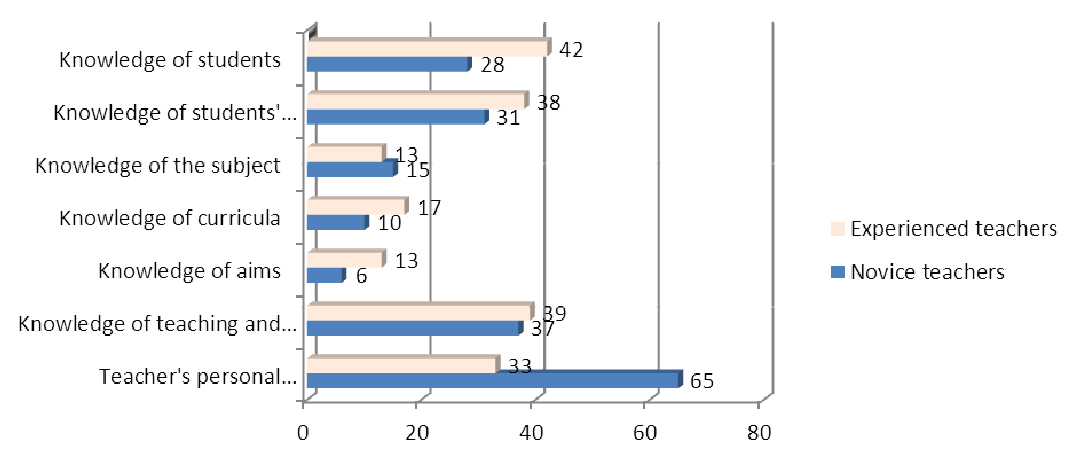

Figure 1. Teachers' views on professionalism (numerically).

\subsection{Expressions of strengths and weaknesses as teachers by novice and experienced teachers}

Opinions regarding strengths and weaknesses in working as teachers were divided into four main groups:

1.Teaching and teaching technology, including preparation of lessons and giving lessons; control and evaluation of the students' knowledge; use of different methods etc.

2. Communication with
a) students
b) colleagues
c) parents

3. Knowledge of the subject

4. Teacher's personal characteristics

357 keywords were counted in total. The largest number of reflections (136) was about teaching and teaching technology (see Figure 2). 


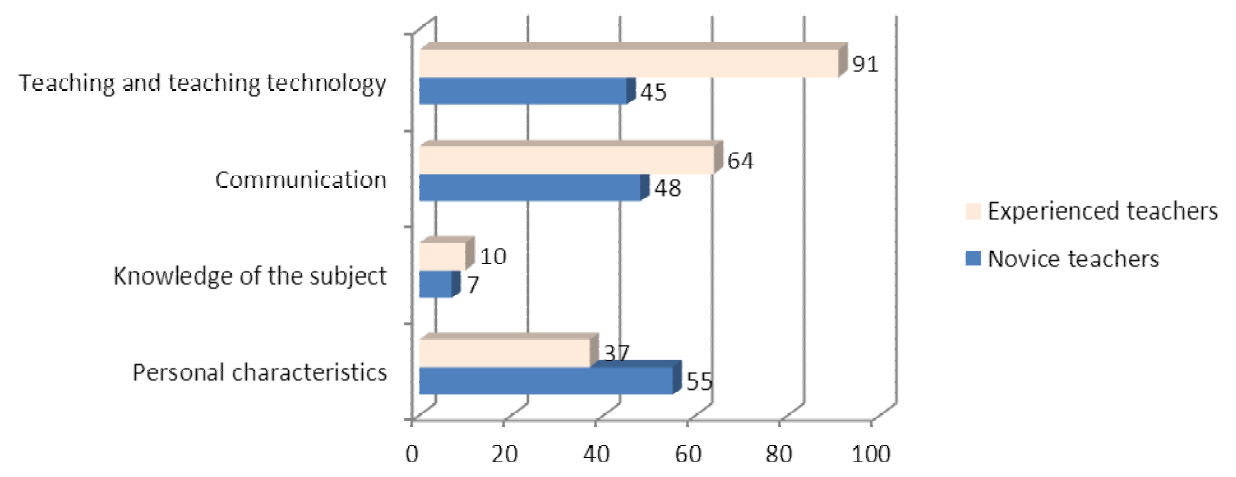

Figure 2. Expressions of strengths and weaknesses as teachers by novice and experienced teachers (numerically).

Opinions related to teaching and teaching technology were expressed the most in both groups $(n=136)$, albeit divided disproportionally between novice and experienced teachers: 91 opinions from the experienced and 45 from the novice teachers. In addition to differences in numbers, there was also variation in the type of problems. The circle here was wider in the case of experienced teachers; novice teachers focussed more on issues related to using modern technology. The novice teachers regarded the use of IT equipment as a strength in teaching and were proud of it ("I use IT equipment and..."); at the same time, their experienced colleagues had problems with it. Some said: "My methods are probably outdated..." (FE) and "The problem for me as a teacher is that the students are more advanced in using modern technology" (ME).

Experienced teachers mentioned the formation of students' learning skills more often, wherein development of discussion and thinking skills et al. was highlighted separately. Additionally, the experienced teachers stressed the aspect of planning and named a variety of aspects related to grading and assessing, stressing these as their strengths. For example, "I'm objective when it comes to grading and I always explain the grade given" (FE).

In contrast, the thoughts expressed on their weaknesses by the novice teachers often involved problems with grading and assessing the students. For example, "I've been told that I'm too accommodating with the students" (FN). It is interesting to note that the novice teachers expressed far fewer thoughts regarding these issues.

Both the novice and experienced teachers mentioned numerous aspects related to communication (112 keywords: 64 from experienced and 48 from novice teachers). These communication-related opinions were divided into three groups: communication with students; communication with colleagues; and communication with parents. Of the thoughts expressed, aspects of communication with students were stressed the most ("I think my relationship with students is very good" (FE); "I think one of my strengths is my ability to support the students and create a friendly atmosphere in the classroom" (FN). 
Experienced teachers saw their ability to maintain discipline as a strength. They stressed the importance of discipline and the teacher's role in keeping order. In contrast, the novice teachers noted that they had problems with this and regarded it as a weakness: "This in my second year as a teacher. I spent my first year focussing on discipline". These examples show that communication with students is seen as both a strength and a weakness. In communication with colleagues willingness to cooperate is an important keyword that was often regarded as a strength.

Thoughts related to knowledge of the subject were only presented 17 times. Such a result seems natural and should be understood without focussing on it unduly. For example: "My strengths are knowledge of the subject and connecting it to other subjects" (FN).

Regarding personal characteristics, 55 of the 92 descriptions presented were given by novice teachers, which clearly expresses a focus on the teacher's personality and one's own personality that is often common with new teachers (comparable to the results of another study). "I am positive"; "Lack of authority is my weakness"; "I am a very quick person and it is visible in my lessons" (FN) etc.

When describing themselves as teachers, the experienced teachers wrote about their personal characteristics on 37 occasions. Personal characteristic features were described both as weaknesses ("My weakness is poor planning skills" or "I can't tolerate stress, such as yelling parents") and strengths ("I can remain calm, patient, understanding..."; "Teaching the sciences requires persistence and calmness"). The respondents themselves and professional teachers generally were mostly characterised using positive features. Thus, positive features dominated, but personal weaknesses were also mentioned.

\section{Discussion and conclusions}

Teaching is a focused activity that includes planning, delivery, and reflection phase (Krull 2000, Krull 2009). This study was focused at the last phase of teaching - reflection. We studied teachers' views on professionalism using their reflective writings and essays to identify the differences in these understandings among novice and experienced teachers. 387 keywords were counted from the essays entitled "What makes a teacher professional?" Overlaps and expressions with similar meanings were grouped under 36 subcategories. The keywords were divided into seven broader areas (six categories of practical knowledge and beliefs by Van Driel and colleagues and one additional category). Secondly, the teachers had to write about their strengths and weaknesses as teachers. 357 keywords were counted from these writings. In the discussion we draw conclusions on the results of both writings. What were the differences and similarities in the essays and reflective writings of the novice and experienced teachers?

Substantive differences in the essays and reflective writings were related to issues regarding the use of technology. The novice/younger teachers mentioned elearning often; the experienced/older teachers barely mentioned it at all. The 
novice teachers stressed the technological aspects of teaching and listed the skill of using modern IT equipment as one a professional teacher should have. While the novice teachers underlined technology, the experienced teachers placed more emphasis on the teacher's role as an educator. The novice teachers see the teacher's role as making students work independently. The main difference was that the younger teachers had greater hopes and expectations regarding IT devices and digital learning, whereas their older colleagues felt that the expanding esystem used to date would not solve the issues related to learning and teaching in school. The technology which is meant to ease teachers' work has a questionable value for older teachers. Most of the older respondents - i.e. experienced teachers - do not question the ever-expanding opportunities of e-learning, but they highlight that it cannot replace real communication between a student and a teacher. Nevertheless, modern teaching requires high-level knowledge of technology, because with it one can enrich the study process. Like one novice teacher said that modern students grow up surrounded by technology and this must be taken into account. Older, experienced teachers tend to be behind students when it comes to knowledge of technology. The experienced teachers mentioned technological capabilities on only a few occasions, instead stressing keywords related to educating the students in a traditional manner. Previous studies about using IT point to comparative results. Lee and Tsai (2010) who examined teachers' attitudes regarding Web-based instruction pointed out that older and more experienced teacher had lower levels of self-efficacy with respect using the IT, though younger teachers with more experience of using IT had higher levels of self-efficacy with respect to new technology.

Experienced teachers stressed more aspects related to the knowledge of the students and teacher's role as an educator. Also, the experienced teachers mentioned aspects related to discipline and order more often: they see their ability to maintain order in the classroom as a strength, and it is important to them. The novice teachers also consider order in the classroom relevant but have trouble ensuring it and thus see it as a weakness. This finding from our study is in accordance with previous studies. The ability of teachers to effectively discipline students is, according to McCormick and Shi (1999) and Lewis, Pomi, Qui and Katz (2005), integrally related to teachers' sense of professional adequacy.

In several respects the novice teachers' opinions of the image of a professional teacher overlapped with those of the experienced teachers. Most of the similarities emerged with keywords noting personal characteristics (professional teachers must be good communicators, balanced and willing to cooperate) and education and knowledge (professionals must be educated and must know the subject well). Both the novice and experienced teachers felt that people should study in order to become teachers. For instance, it was noted that to become a professional teacher you have to study and work for years. This is similar to the international understanding of the essence of a teacher's work: becoming an expert in teaching is a lengthy process, requiring approximately 10,000 hours of practical work in a classroom (Berliner 1994, Berliner 2001, Ericsson 1996). 
Both the novice and experienced teachers regarded readiness to learn more and undertaking training as a feature of professional teachers. Both groups noted the importance of skills in cooperating with students and colleagues. The novice and experienced teachers alike value communication. Views on issues related to curricula were also largely similar between the groups. The sheer volume of curricula and being overburdened in trying to get through everything were highlighted. Kagan (1992) also points out that a teacher at the beginning of his/her professional career engages most with himself or herself. Later he/she will pay attention to teaching and students learning/outcomes.

This study has several limitations. The limitation for greater generalisations is due to the small number of participants $(n=20)$. The small selection is due to the fact that the work done with each respondent was time-consuming and resourceheavy. Additionally, the teachers participated in the study of their own free will. The possibility that the results could be different with a different sample cannot be ruled out. The practical knowledge of teachers is unique. Teachers may express their understanding of a professional teacher differently. The teachers' evaluations of their own actions as teachers and their personal strengths and weaknesses vary. Although, as with many other qualitative approaches, validity cannot be completely checked with this method either, this technique - reflective writing nevertheless offers a systematic approach to the study of the practical knowledge of a teacher.

Through reflective activities teachers can be directed towards analysing and thinking about their professional skills and developing them further. This kind of writing - the analysis of one's own work - develops the self-analysis skills of novice teachers. For experienced teachers, a better understanding of one's competence helps to achieve maximum quality in one's professional work.

\section{Acknowledgements}

Greatest thanks go to the teachers who participated in this study. We thank Professor Paulien Meijer for her consultations. This article was supported by ESF project No. 1.2.0401.09-0070 Doctoral School of Educational Sciences.

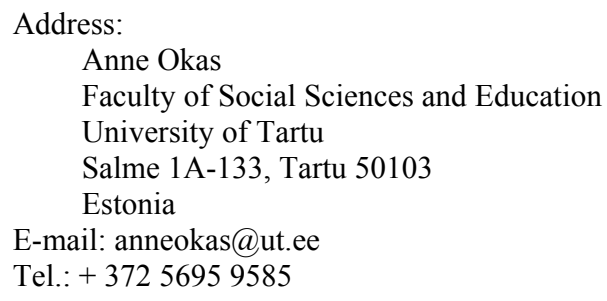




\section{References}

Beijaard, Douwe and Nico Verloop (1996) “Assessing teachers' practical knowledge”. Studies in Educational Evaluation 22, 3, 275-286.

Berliner, David C. (1994) "Expertise: The wonders of exemplary performance". In Creating powerful thinking in teachers and students, 141-186. John N. Mangieri and Cathy Collins Block, eds. Ft. Worth, TX: Holt, Rinehart \& Winston.

Berliner, David C. (2001) "Learning about and learning from expert teachers". International Journal of Educational Research 35, 463-482.

Broekman, Harrie and Heather Scott (1999) "Teacher development by using writing as a tool". Teacher Development 3, 2, 233-248.

Calderhead, James (1996) "Teachers: beliefs and knowledge". In Handbook of Educational Psychology, 709-725. David C. Berliner and Robert C. Calfee, eds. New York: Macmillan.

Corrigan, Dean C. and Martin Haberman (1990) "The context of teacher education". In Handbook of research on teacher education, 195-211. W. Robert Houston, ed. New York: Macmillan Pub. Co.

Day, Christopher (2002) "School reform and transitions in teacher professionalism and identity". International Journal of Educational Research 37, 8, 677-692.

Eraut, Michael (2008) Developing professional knowledge and competence. New York: Routledge Falmer, Taylor and Francis Group.

Ericsson, K. Anders, ed. (1996) The road to excellence: the acquisition of expert performance in the arts and sciences, sports and games. New Jersey: Lawrence Erlbaum Associates, Inc.

Evans, Linda (2008) "Professionalism, professionality and the development of education professionals". British Journal of Educational Studies 56, 1, 20-38.

Fenstermacher, Gary D. (1994) "The knower and known: the nature of knowledge in research on teaching". Review of Research on Teaching 20, 3-56.

Fuller, Frances F. (1969) "Concerns of teachers: A developmental conceptualization". American Research Journal 6, 2, 207-226.

Fuller, Frances F. (1970) Personalized education for Teachers: one application of the teacher concerns model. Austin: University of Texas, Research \& Development Centre for Teacher Education.

Fuller, Frances F. and Oliver H. Bown (1975) "Becoming a teacher". In Teacher education: 74th yearbook of the national society for the study of education II, 25-52. Kevin Ryan, ed. Chicago: University of Chicago Press.

Goldhaber, Dan D. and Dominic J. Brewer (2000) "Does teacher certification matter? High school teacher certification status and student achievement". Educational Evaluation and Policy Analysis 22, 129-145.

Hargreaves, Andy (2001) "Teaching as a paradoxical profession: implications for professional development". In Symposium proceedings on continuing teacher education and school development, 26-38. Panos Xochellis and Zoi Papanaoum, eds. Thessaloniki: Department of Education, School of Philosophy AUTH.

Hatton, Neville and David Smith (1995) "Reflection in teacher education: towards a definition and implementation". Teaching and Teacher Education 11, 1, 33-49.

Hays, Richard and Simon Gay (2011)"Reflection or 'pre-reflection': what are we actually measuring in reflective practice?" Medical Education 45, 2, 116-118.

Hoover, Linda (1994) "Reflective writing as a window on preservice teachers' thought processes". Teaching and Teacher Education 10, 83-93.

Hoyle, Eric and P. D. John (1995) Professional knowledge and professional practice. London: Cassell.

Kagan, Dona M. (1992) "Professional growth among preservice and beginning teachers". Review of Educational Research 62, 2, 129-169.

Korthagen, Fred A. J. (2001) Linking practice and theory: the pedagogy of realistic teacher education. Mahwah, NJ: Lawrence Erlbaum Associates, Inc. 
Krull, Edgar (2000) Pedagoogilise psühholoogia käsiraamat, 47-50. [Handbook of educational psychology.] Tartu: Tartu Ülikooli Kirjastus.

Krull, Edgar (2002) Eesti õpetaja pedagoogilised arusaamad, arvamused ja hoiakud millenniumivahetusel. Küsitluse "Töö klassis õpetaja pilguga" põhijäreldused. [Estonian teachers' educational attitudes and beliefs at turn of the millennium. Main conclusions from the inquiry "Working in the classroom seen through teachers' eyes".] Tartu: Tartu Ülikooli Kirjastus.

Krull, Edgar (2009) "Normaalkoolid: kas anakronism või õpetajakoolituse tulevikI [Finnish normal schools: anachronism or future of teacher education.] Akadeemia (Tartu) 21, 3, 524-547.

Krull, Edgar and Ingrid Raudsepp (2010) "Perspectives for Optimizing the School Practicum for Student Teachers Through a Study of Dutch, Estonian and Finnish Experiences". In Teacher's Personality and Professionalism. Estonian Studies in Education, 141-158. J. Mikk, M. Veisson, P. Luik, eds. Frankfurt am Main: Peter Lang Publishing Group.

Krull, Edgar, Äli Leijen, Madis Lepik, Jaan Mikk, Leida Talt,s and Tiia Õun, eds. (2013) Õpetajate professionaalne areng ja selle toetamine. Projekti Opetajate professionaalne areng ja selle toetamine tulemused õpetajakoolituse teenistuses. [Teachers professional development and its support. Results of the project Teachers' professional development and its support in service of teacher education.] Tartu: Eesti Ülikoolide Kirjastus.

Lee, Min-Hsien and Chin-Chung Tsai (2010) "Exploring teachers' perceived self efficacy and technological pedagogical content knowledge with respect to educational use of the World Wide Web". Instructional Science 38, 1, 1-21.

Lewis, Ramon, Shlomo Pomi, Xing Qui, and Yaacov Katz (2005) "The classroom discipline and student misbehavior in Australia, China and Israel". Teaching and Teacher Education 21, 6, 729-741.

Mausethagen, Solvi and Lise Granlund (2012) "Contested discourses of teacher professionalism: current tensions between education policy and teachers' union". Journal of Education Policy $27,6,815-833$.

McCormick, John and Guoxing Shi (1999) “Teachers' attributions of responsibility for their occupational stress in the People's Republic of China and Australia". British Journal of Educational Psychology 69, 3, 393-407.

Meijer, Paulien C., Nico Verloop, and Douwe Beijaard (1999) "Exploring language teachers' practical knowledge about teaching reading comprehension". Teaching and Teacher Education 15, 1, 59-84.

Meijer, Paulien C., Nico Verloop, and Douwe Beijaard (2002) "Multi-method triangulation in a qualitative study on teachers' practical knowledge: an attempt to increase internal validity". Quality and Quantity 36, 145-167.

Meijer, Paulien Catherine (1999) Teachers' practical knowledge: teaching reading comprehension in secondary education. Doctoral Dissertation. The Netherlands: Leiden University.

Mizell, Hayes (2010) Why professional development matters? Oxford, OH: Learning Forward.

Niemi, Hannele and Viljo Kohonen (1995) Towards new professionalism and active learning in teacher development. Tampere: Department of Teacher Education in Tampere University.

Okas, Anne, Marieke Van der Schaaf, and Edgar Krull (2013a) "Algajate ja kogenud õpetajate praktilise teadmise avaldumine tunnisündmuste kommenteerimisel stimuleeritud meenutuse meetodil". [Teachers practical knowledge in novice and experienced teachers' comments on classroom interactions.] Eesti Haridusteaduste Ajakiri 1, 25-45.

Okas, Anne, Marieke Van der Schaaf, and Edgar Krull (2013b) "Novice and experienced teachers personal practical knowledge in planning lessons". In Estonian Studies in Education, 27-43. Jaan Mikk, Marika Veisson, Piret Luik, eds. Frankfurt am Main: Peter Lang Verlag.

Poldner, Eric, Marieke Van der Schaaf, Robert-Jan Simons, Johannes Van Tartwijk, and Guus Wijngaards (2014) "Assessing student teachers reflective writing through quantitative content analysis". European Journal of Teacher Education 37, 3, 348-373.

Schepens, Annemie, Antonia Aelterman and Hilda Van Keer (2007) "Studying learning processes of student teachers with stimulated recall interviews through changes in interactive cognitions". Teaching and Teacher Education 23, 457-472. 
Schön, Donald A. (1983) The reflective practitioner: how professionals think in action. London: Temple Smith.

Šteh, Barbara and Barica Marentic Požarnik (2005) “Teachers' perceptions of their professional autonomy in the environment of systemic change". In Teacher professional development in changing conditions, 343-363. Douwe Beijaard, Paulien C. Meijer, Greta Morine-Dershimer and Harm Tillema, eds. Springer.

The Oxford reference dictionary (1992) Oxford University Press.

Van der Schaaf, Marieke (2005) Construct validation of teacher portfolio assessment. Procedures for improving teacher competence assessment illustrated by teaching students research skills. (Doctoral dissertation.) Utrecht University.

Van der Schaaf, Marieke and Karel M. Stokking (2008) "Developing and validating a design for teacher portfolio assessment". Assessment \& Evaluation in Higher Education 33, 3, 245-262.

Van Driel, Jan H, Nico Verloop, and Wobbe de Vos (1998) "Developing science teachers' peadgogical content knowledge". Journal of Research in Science Teaching 35, 673-695.

Webb, Rosemary, Graham Vulliamy, Seppo Hämäläinen, Anneli Sarja, Eija Kimonen, and Raimo Nevalainen (2004) "A comparative analysis of primary teacher professionalism in England and Finland". Comparative Education 40, 1, 83-107.

Westbury, Ian, Sven-Erik Hansen, Pertti Kansanen, and Ole Björkvist (2005) “Teacher education for research-based practice in expanded roles: Finland's experience". Scandinavian Journal of Educational Research 49, 5, 475-485. 